UDC 331.1

DOI: $10.25140 / 2411-5215-2020-1(21)-321-331$

Igor Oliychenko, Maryna Ditkovska

\title{
FEATURES AND WAYS OF IMPROVING THE PERSONNEL MANAGEMENT OF THE TRADE ENTERPRISE
}

\author{
Ігор Олійченко, Марина Дітковська \\ ОСОБЛИВОСТІ ТА ШЛЯХИ ВДОСКОНАЛЕННЯ УПРАВЛІННЯ \\ ПЕРСОНАЛОМ ТОРГОВЕЛЬНОГО ПІДПРИСМСТВА
}

\author{
Игорь Олейченко, Марина Дитковская \\ ОСОБЕННОСТИ И ПУТИ СОВЕРШЕНСТВОВАНИЯ УПРАВЛЕНИЯ \\ ПЕРСОНАЛОМ ТОРГОВОГО ПРЕДПРИЯТИЯ
}

In the conditions of development of the national economy, which requires technological and structural transformations, informatization of the main processes, there is a significant increase in the role of personnel in the success of trade enterprises. Personnel is the main productive force in solving issues of economic growth and efficient operation of enterprises, ensuring their competitiveness. The article examines the process of improving the personnel management system of a trading enterprise, analyzes the methods of personnel management, features of personnel policy. The authors analyzed the activities of the enterprise, assessed its composition, personnel structure, tasks and factors of personnel management and formed proposals and measures to improve personnel management at the enterprise. To improve the enterprise needs to implement a competency-based approach to personnel management and improve the training system, retraining of employees and training of administrative and managerial staff.

Keywords: personnel; personnel management; personnel structure; assessment; efficiency; forecast; competency approach; retraining; advanced training.

Fig.: 1. Table: 4. References: 17.

В умовах розвитку національної економіки, яка потребує технологічних $i$ структурних перетворень, інформатизаиії основних процесів, спостерігається значне зростання ролі персоналу в успішності функиіонування торговельних підприємств. Персонал є основною продуктивною силою у вирішенні питань економічного зростання $i$ ефективної роботи підприємств, забезпечення їх конкурентоздатності. У статті досліджується процес удосконалення системи управління персоналом торгівельного підприємства, аналізується методи управління персоналом, особливості кадрової політики. Автори провели аналіз діяльності підприємства, оиінку його складу, структури персоналу, завдання та чинники управління персоналом та сформували пропозиції та заходи щодо удосконалення управління персоналом на підприємстві. Для удосконалення підприємство потребує впровадження компетентнісного підходу до управління персоналом та удосконалення системи навчання, перепідготовки праиівників та підвищення кваліфікаиії адміністративно-управлінського персоналу.

Ключові слова: персонал; управління персоналом; структура персоналу; оцінка; ефективність; прогноз; компетентнісний підхід; перепідготовка, підвищення кваліфікації.

Рис.: 1. Табл. 4. Бібл.: 17.

В условиях развития начиональной экономики, которая требует технологических и структурных преобразований, информатизаиии основных процессов, наблюдается значительный рост роли персонала 6 успешности функционирования торговых предприятий. Персонал является основной производительной силой 6 решении вопросов экономического роста и эффективной работы предприятий, обеспечения их конкурентоспособности. В статье исследуется процесс совершенствования системы управления персоналом торгового предприятия, анализируется методы управления персоналом, особенности кадровой политики. Авторы провели анализ деятельности предприятия, оченку его состава, структуры персонала, задачи и факторы управления персоналом и сформировали предложения и мероприятия по совершенствованию управления персоналом на предприятии. Для усовершенствования предприятие требует внедрения компетентностного подхода к управлению персоналом и усовершенствование системы обучения, переподготовки работников и повышение квалификачии административно-управленческого персонала.

Ключевые слова: персонал; управление персоналом; структура персонала; оченка; эффективность; прогноз; компетентностный подход; переподготовка; повышение квалификаиии.

Рис.: 1. Табл.: 4. Библ.: 17

JEL Classification: M12

Problem statement. Improving the efficiency of personnel management in modern conditions is of particular importance because the main and most influential factor in ensuring the efficiency of the economy of Ukraine is the system of human resource management. In modern conditions, personnel management at enterprises of all forms of ownership does not meet the existing needs of the market. This situation is due to the influence of echoes of the command-administrative system and the rapid change in the conditions of operation of enterpris-

( Олійченко І. М., Дітковська М. Ю., 2020 
ФІНАНСОВІ РЕСУРСИ: ПРОБЛЕМИ ФОРМУВАННЯ ТА ВИКОРИСТАННЯ

es. The human factor is playing an increasing role in ensuring the competitiveness and efficiency of enterprises in a market economy. Properly created personnel potential creates the preconditions for the long-term and successful operation of the enterprise in the market of goods or services. Classical methods and techniques of personnel management today do not meet the requirements of modern business; they are not able to provide effective relationships in an unstable area. In modern conditions, the competitiveness of enterprises and organizations depends on the level of formation of effective personnel policy at the enterprise, which would meet the requirements of the strategic goals of the company and its mission. Wellformed personnel policy is especially important at private enterprises, where the most modern and effective technologies that have positively proven themselves should be used.

Analysis of recent research and publications. The following domestic scientists studied the personnel management system at enterprises: V. Adamchuk, V. Gerasimchuk, G. Zavinovska, V. Prasol, I. Lukinov, J. Petrovich, A. Kolot, M. Grinyova, A. Afonina, G. Shchokin, E. Libanova, D. Goddess, G. Kopets.

Problems of personnel management of a commercial enterprise are the subject of research by a number of domestic and foreign scientists, such as M. Aksenova, O. Gavrish, E. Gorshkova, L. Dovgan, I. Kreidych, O. Kukharkova, O. Krushelnytska, D. Melnychuk, N. Sytnyk etc.

Allocation of the unsolved earlier parts of the overall problem. Ukrainian trade enterprises still need to improve the personnel management system and despite the wide range of research, the problems of development and personnel management in the enterprise remain debatable and need further study in the light of changes in market competition and globalization.

The aim of the paper is to study and analyze the personnel management system of a commercial enterprise, identify problems of its development and develop recommendations for its improvement through the introduction of innovative technologies and modernization of personnel development.

The main results of the study. The personnel management system, the core of which is a functional subsystem, includes four more subsystems: information, socio-psychological, financial and legal. The main task that is solved with this system is the effective management of human resources of the organization. The functional core of the management system is to solve the following tasks: search, selection, training and staffing; optimal placement of staff within the organization; efficient use of personnel; management of socio-psychological factors. A secondary function, as in the implementation of personnel management systems, is to create favorable conditions for work. The personnel management system of the organization, which takes into account the specifics of its activities, is a set of methods and technologies and work with personnel based on certain principles [6].

Any management system consists of three technological blocks: search technology, selection and formation of personnel; technologies for staff development and training; technologies for the optimal use of the ability and resources of the current staff. The successful economic activity of the enterprise largely depends on how effectively the personnel management system works. And the condition for the coordinated work of this system is the use of systems analysis, as well as other methods that allow to adapt it to the needs and requirements of the enterprise. Thus, the method of comparison is used in order to analyze and compare the management systems operating in the enterprise with the management system of another, more successful enterprise engaged in the same production activities. To create an optimal model and frame management system, we also use the method of sequential substitution, in which the value of each factor that affects the functionality of this system changes sequentially [10]. Management systems use a variety of methods, approaches and techniques, as well as provide the opportunity: to organize, target (direct) and effectively organize the performance of functions inherent in personnel, procedures and operations necessary for the implementation of managerial influence. Collectively, the methods of management, which are used to determine and achieve its goal, act as methods of management. 
ФІНАНСОВІ РЕСУРСИ: ПРОБЛЕМИ ФОРМУВАННЯ ТА ВИКОРИСТАННЯ

Methods of personnel management are also called ways to influence the team or individual employees in order to coordinate their activities and in the process and work to achieve the whole and the organization. Depending on the content of managerial influence in management and distinguish between organizational and administrative, economic and socio-psychological methods of management. The choice of method in management in the subject of management depends on the value and tradition and social group, the level of development of productive forces, production relations in societies and the type of activity and object in the management [16]. In a constantly changing global world, trade enterprises must observe the development of an extremely competitive environment, characterized by economic and social turbulence, the impact of three main variables: technological, economic and competitive. The basis of any organization and its main wealth are people. In the new economy, the role and importance of man in economic structures not only did not fall but on the contrary - increased [13].

The personnel management system in a modern trading company, regardless of ownership, is the most powerful tool for competitiveness and development. Therefore, there is a need to increase the efficiency of the personnel management system taking into account the requirements of a market economy. The management of an enterprise operating in market conditions places high demands on the professionalism of management staff. The problem of personnel management in a commercial enterprise is a key point in the restructuring of the entire management system [11]. The personnel management service implements the personnel policy and coordinates the labor management activities of the enterprise; carries out the necessary expansion of functions for the creation of new systems of stimulation of labor activity, carries out management of the market of labor resources, creates personnel reserves for management staff. The personnel management system is extremely complex and provides continuous improvement of methods of work with personnel and use of achievements of domestic and foreign science, the best industrial experience [8].

In fact, the functioning of the system of implementation of the personnel management process is ensured by its subsystems, each of which is responsible for a separate function of the management process: the subsystem of planning work with personnel; subsystem of organization of personnel work; subsystem of the motivation of results of work and behavior; control subsystem. The structure of the personnel management system of any enterprise depends on the scale of the organization, its territorial location, the nature of activities and other factors. At large enterprises there is a personnel management service, which provides selection and hiring of personnel, personnel evaluation; organization of staff training and advanced training; analysis of qualitative composition and staff turnover; certification and staff rotation; payroll management; organization of accounting and reporting [9].

Unlike large enterprises, small ones, due to limited financial and other resources, usually do not have full-fledged personnel management services and do not pursue large-scale personnel policies. In particular, in medium-sized enterprises, issues related to the functions of personnel management are dealt with by individual specialists, whose responsibilities are determined by job descriptions. In small enterprises, these functions are entrusted to the head of the enterprise, who provides planning of work with staff, organization of staff work, the motivation of work results and behavior, as well as control of work performed [15]. The technology of personnel management of the organization involves the organization of recruitment, selection, hiring, business, career guidance and adaptation, training, management of business careers and career advancement, motivation and organization of work, conflict and stress management, sustainable development, staff release. These include issues of interaction between the leaders of the organization with trade unions and employment services [7].

There are concepts of "staff technology" and "personnel technology". Staff technologies are professional techniques for working with staff, which ensure the implementation of targeted personnel activities. Used constantly in the preparation and adoption of management decisions 
ФІНАНСОВІ РЕСУРСИ: ПРОБЛЕМИ ФОРМУВАННЯ ТА ВИКОРИСТАННЯ

regarding personnel. They are developed at the enterprise and have mostly traditional forms. Personnel technology is a set of methods of personnel management, which are focused on assessing and improving the "human resource" of the enterprise. They are used mainly in a specific situation and are implemented through a consultative process. They are developed outside the enterprise and are adapted to its culture and in accordance with the requirements of practical efficiency [1]. The main purpose of management personnel technology is to optimize and increase the effectiveness of the management process in working with staff, which is achieved through the search and application of more effective methods of personnel management, which contribute to streamlining the management process by excluding certain activities or operations, including those not necessary to achieve goals and management tasks. It is the personneltechnologies that minimize the costs of personnel management of the enterprise, which helps to increase the efficiency of its use [14]. The effectiveness of personnel management of the trade enterprise depends on: the formation of the company's reputation as a good employer; development of the system of adaptation to the external and internal labor market; use of payment systems based on the principles of taking into account the personal contribution and the level of professional competence of each employee; availability of a flexible system of work organization; employee participation in discussing problems and making management decisions; delegation of authority to subordinates; organization of an effective communication system, which is an integrating factor of the whole model of strategic personnel management [4].

Problems in personnel management of the enterprise are often found in the assessment of the internal and external environment [17]. For example, the results of the SWOTanalysis of the company Technopolis-1 LLC (Chernihiv branch) indicate a lack of attention to staff development, insufficient level of staffing (Fig. 1). Technopolis-1 LLC is a Ukrainian chain of electronics and home appliances supermarkets, founded in 1999 in Ukraine under the Eldorado brand.

\begin{tabular}{|c|c|c|}
\hline & Opportunities & Threats \\
\hline & $\begin{array}{l}\text { Entering new markets; } \\
\text { Increasing the volume of e-commerce; } \\
\text { Increasing the level of income and pur- } \\
\text { chasing power of the population; } \\
\text { The decrease in prices for goods }\end{array}$ & $\begin{array}{l}\text { Changes in the needs and tastes of } \\
\text { consumers; } \\
\text { Declining living standards; } \\
\text { Rising inflation; Change of customs } \\
\text { tariffs; } \\
\text { Increasing pressure from competitors }\end{array}$ \\
\hline Strengths & "Strength and opportunities" & "Strength and threats" \\
\hline $\begin{array}{l}\text { Wide range of goods; } \\
\text { High-quality control; } \\
\text { Competitive price. }\end{array}$ & $\begin{array}{l}\text { Entering new markets, which will attract } \\
\text { new buyers; } \\
\text { Identification of reserves to reduce the } \\
\text { cost and price of goods; Increasing the } \\
\text { range }\end{array}$ & $\begin{array}{l}\text { Stimulation and implementation of } \\
\text { the results of scientific and techno- } \\
\text { logical progress; High competition of } \\
\text { domestic producers; Substantiated } \\
\text { optimization of the product range } \\
\end{array}$ \\
\hline Weaknesses & "Weaknesses and opportunities" & "Weaknesses and threats" \\
\hline $\begin{array}{l}\text { Insufficient attention to staff } \\
\text { development } \\
\text { Limited financial resources } \\
\text { Insufficient level of staff }\end{array}$ & $\begin{array}{l}\text { Activation of the advertising policy will } \\
\text { improve the image of the enterprise; } \\
\text { Improving the technology of sales of } \\
\text { goods }\end{array}$ & $\begin{array}{l}\text { Rising prices for goods } \\
\text { Loss of potential consumers }\end{array}$ \\
\hline
\end{tabular}

Fig. 1. Matrix of SWOT-analysis of Technopolis-1 LLC

The staff of Technopolis-1 LLC consists of all employees who participate in the economic activity of the enterprise on the basis of employment contracts. The need for staff by type of position and number of employees is determined in the staffing schedule of the enterprise, which is approved by the head of the enterprise annually. The staffing schedule also determines the number of monthly salaries of employees. Employees of the enterprise are divided into managers, experts, specialists and employees. The composition and structure of the staff of Technopolis-1 LLC for 2017-2019 is presented in table 1. 
ФІНАНСОВІ РЕСУРСИ: ПРОБЛЕМИ ФОРМУВАННЯ ТА ВИКОРИСТАННЯ

Table 1

Assessment of the company's staffing in 2017-2019

\begin{tabular}{|l|c|c|c|c|c|c|c|}
\hline \multirow{2}{*}{ Indicators } & \multirow{2}{*}{$\mathbf{2 0 1 7}$} & $\mathbf{2 0 1 8}$ & $\mathbf{2 0 1 9}$ & $\begin{array}{c}\text { Absolute deviation } \\
\text { from the previous } \\
\text { period }\end{array}$ & & \multicolumn{2}{c|}{$\begin{array}{c}\text { Growth rate to the } \\
\text { previous period, \% }\end{array}$} \\
\cline { 5 - 9 } & & & & 2018 & 2019 & 2018 & 2019 \\
\hline Number of employees, persons, including: & 43 & 43 & 45 & 0 & 2 & 0 & 4,7 \\
\hline - managers, individuals & 4 & 3 & 3 & -1 & 0 & -25 & 0,0 \\
\hline - specific weight \% & 9,3 & 7,0 & 6,7 & $-2,3$ & $-0,3$ & -25 & $-4,4$ \\
\hline - - employees, persons & 10 & 10 & 10 & 0 & 0 & 0 & 0,0 \\
\hline - specific weight, \% & 23,3 & 23,3 & 22,2 & 0 & $-1,0$ & 0 & $-4,4$ \\
\hline - specialists, persons & 13 & 13 & 14 & 0 & 1 & 0 & 7,7 \\
\hline - specific weight, \% & 30,2 & 30,2 & 31,1 & 0 & 0,9 & 0 & 2,9 \\
\hline - sales workers, persons & 16 & 17 & 18 & 1 & 1 & 6,3 & 5,9 \\
\hline - specific weight, \% & 37,2 & 39,5 & 40,0 & 2,3 & 0,5 & 6,3 & 1,2 \\
\hline
\end{tabular}

From the table 1, we see that at the enterprise in 2019. There was an increase in staff both as a whole and by individual categories of employees. Thus, the actual number of all staff compared to previous years increased by 2 people due to an increase in the number of sales staff - by 2 people and specialists per 1 person. The number of managers is decreased by 1 person in 2018.

During the analyzed period, the staff structure of Technopolis-1 LLC (Eldorado store in Chernihiv) has not undergone significant changes, the largest share are trade workers, their share during 2017-2019 increased from $37.2 \%$ to $40 \%$, on the second place of specialists, their share increased from $30.2 \%$ to $31.1 \%$, at the same time there is a decrease in the share of employees from $23.3 \%$ to $22.2 \%$ and managers from $9.3 \%$ to $6.7 \%$. Such changes can be explained by the optimization of the administrative staff and the increase in the number of employees.

Unplanned non-fulfillment of the plan by the number of employees of the main activity (including workers) in the period of formation of market relations is a positive factor provided that the planned volume of production with fewer employees is achieved.

The actual growth of employees of the main activity (including trade workers) occurred against the background of a decrease in the volume of marketable products and this is a negative factor and indicates a decrease in the efficiency of the enterprise.

The experience of the company's employees is important for the assessment of working capacity. Estimation of labor resources of Technopolis-1 LLC is characterized by the data given in Table 2. These tables show that for three years the company has slightly increased experienced employees with more than 3 years of experience - their number has increased from 22 to 24 people, and their share increased from $51.2 \%$ to $53.3 \%$. Instead, the share of employees with up to 1 year of service increased from $11.6 \%$ to $13.3 \%$.

The share of employees with 2 to 3 years of experience in the company increased during 2017-2019 from $27.9 \%$ to $28.9 \%$, and the share of employees with 1 to 2 years of experience decreased from $9.3 \%$ to $4.4 \%$. Thus, Technopolis-1 LLC has a fairly stable workforce.

Table 2

Assessment of labor resources of Technopolis-1 LLC

\begin{tabular}{|l|c|c|c|c|c|c|c|}
\hline \multirow{2}{*}{ Indicators } & \multirow{2}{*}{$\mathbf{2 0 1 7}$} & $\mathbf{2 0 1 8}$ & $\mathbf{2 0 1 9}$ & $\begin{array}{c}\text { Absolute deviation from } \\
\text { the previous period }\end{array}$ & $\begin{array}{c}\text { Growth rate to the } \\
\text { previous period, \% }\end{array}$ \\
\cline { 5 - 9 } & & & & $\mathbf{2 0 1 8}$ & $\mathbf{2 0 1 9}$ & $\mathbf{2 0 1 8}$ & $\mathbf{2 0 1 9}$ \\
\hline \multicolumn{1}{|c|}{} & 2 & 3 & 4 & 5 & 6 & 7 & 8 \\
\hline $\begin{array}{l}\text { Number of employees, persons, } \\
\text { including with experience: }\end{array}$ & 43 & 43 & 45 & 0,0 & 2,0 & 0,0 & 4,7 \\
\hline - up to 1 year, persons & 5 & 4 & 6 & $-1,0$ & 2,0 & $-20,0$ & 50,0 \\
\hline - specific weight, \% & 11,6 & 9,3 & 13,3 & $-2,3$ & 4,0 & $-20,0$ & 43,3 \\
\hline - from 1 to 2 years, persons & 4 & 4 & 2 & 0,0 & $-2,0$ & 0,0 & $-50,0$ \\
\hline - specific weight, \% & 9,3 & 9,3 & 4,4 & 0,0 & $-4,9$ & 0,0 & $-52,2$ \\
\hline
\end{tabular}


ФІНАНСОВІ РЕСУРСИ: ПРОБЛЕМИ ФОРМУВАННЯ ТА ВИКОРИСТАННЯ

End of table 2

\begin{tabular}{|l|c|c|c|c|c|c|c|}
\hline \multicolumn{1}{|c|}{1} & 2 & 3 & 4 & 5 & 6 & 7 & 8 \\
\hline - from 2 to 3 years, persons & 12 & 13 & 13 & 1,0 & 0,0 & 8,3 & 0,0 \\
\hline - specific weight, \% & 27,9 & 30,2 & 28,9 & 2,3 & $-1,3$ & 8,3 & $-4,4$ \\
\hline - over 3 years, persons & 22 & 22 & 24 & 0,0 & 2,0 & 0,0 & 9,1 \\
\hline - specific weight, \% & 51,2 & 51,2 & 53,3 & 0,0 & 2,2 & 0,0 & 4,2 \\
\hline
\end{tabular}

The movement of labor at Technopolis-1 LLC is presented in table 3. Indicators in table 3 show that the company's turnover ratio on acceptance increased in the reporting period by $50 \%$, staff turnover rate - by $33.78 \%$. The increase in staff turnover is due to a $40 \%$ increase in voluntary redundancies compared to the previous period.

Table 3

Labor movement at Technopolis-1 LLC for 2017-2019

\begin{tabular}{|c|c|c|c|c|c|c|c|}
\hline \multirow[t]{2}{*}{ Indicators } & \multirow[t]{2}{*}{2017} & \multirow[t]{2}{*}{2018} & \multirow[t]{2}{*}{2019} & \multicolumn{2}{|c|}{$\begin{array}{l}\text { Absolute deviation from } \\
\text { the previous period }\end{array}$} & \multicolumn{2}{|c|}{$\begin{array}{l}\text { Growth rate to the } \\
\text { previous period, \% }\end{array}$} \\
\hline & & & & 2018 & 2019 & 2018 & 2019 \\
\hline $\begin{array}{l}\text { 1. The average number of employ- } \\
\text { ees, persons }\end{array}$ & 43 & 43 & 45 & 0,0 & 2,0 & 0,0 & 4,7 \\
\hline $\begin{array}{l}\text { 2. Hired new employees during the } \\
\text { year, persons }\end{array}$ & 3 & 6 & 9 & 3,0 & 3,0 & 100,0 & 50,0 \\
\hline $\begin{array}{l}\text { 3. Employees who left, people, in- } \\
\text { cluding: }\end{array}$ & 4 & 6 & 7 & 2,0 & 1,0 & 50,0 & 16,7 \\
\hline - voluntarily & 3 & 5 & 7 & 2,0 & 2,0 & 66,7 & 40,0 \\
\hline - for violation of labor discipline & - & - & - & & & & \\
\hline $\begin{array}{l}\text { 6. Number of employees who } \\
\text { worked for a year }\end{array}$ & 40 & 38 & 38 & $-2,0$ & 0,0 & $-5,0$ & 0,0 \\
\hline 7. Turnover ratio for hiring & 0,07 & 0,14 & 0,20 & 0,07 & 0,06 & 100,00 & 43,33 \\
\hline 8. Turnover ratio for dismissal & 0,09 & 0,14 & 0,16 & 0,05 & 0,02 & 50,00 & 11,48 \\
\hline 9. Staff turnover ratio & 0,07 & 0,12 & 0,16 & 0,05 & 0,04 & 66,67 & 33,78 \\
\hline $\begin{array}{l}\text { 10. The coefficient of constancy of } \\
\text { the personnel of the enterprise }\end{array}$ & 0,93 & 0,88 & 0,84 & $-0,05$ & $-0,04$ & $-5,00$ & $-4,44$ \\
\hline
\end{tabular}

Particular attention should be paid to staff turnover, as turnover, as has been said, reduces productivity in the enterprise. In order to develop measures aimed at securing workers, it is necessary to know the specific reasons for voluntary redundancies (difficult working conditions, low wages, unsatisfactory career prospects, dissatisfaction with the profession, unsatisfactory morale in the team, etc.) and violations of labor discipline. It is important to establish the dynamics of labor turnover indicators to determine in which direction these indicators are changing, what impact they have on the conditions of organization of labor and production in the enterprise as a whole and in its individual sections [2].

Tensions in the provision of the enterprise with labor resources can be removed through more efficient use of available labor, increased productivity, intensification of production, improving the organization and technology of production, the introduction of more productive equipment.

Thus, the analysis of the composition and structure of the staff of Technopolis-1 LLC showed that the composition of the staff is determined by the specifics of the enterprise. The quality of staff is improving, but the company needs to pay attention to staff turnover issues, as this may lead to negative consequences in the future.

The analysis of the personnel management system of Technopolis-1 LLC showed that the efficiency of the enterprise has negative changes, the volume of activity and number of personnel at the enterprise decreases, staff turnover increases and insufficient attention is paid to personnel development. It should be noted that inefficient use of staff significantly reduces the level of skills and efficiency of workers, productivity, increases the material and moral aging of fixed assets, increases material consumption, leads to a significant increase in production costs and reduced production efficiency. 
ФІНАНСОВІ РЕСУРСИ: ПРОБЛЕМИ ФОРМУВАННЯ ТА ВИКОРИСТАННЯ

As a result, the process of staff turnover at Technopolis-1 LLC is far from unambiguous. For bidders who are fired, the positive moments are the expected increase in income in a new place, the increase in the prospects of the company, the expansion of ties, the acquisition of more money. At the same time, during the period of employment, they lose their salaries, uninterrupted work experience in the organization and the associated benefits; they have to spend money looking for a new place to live.

For the remaining staff, new opportunities for promotion, additional work appear. But the workload increases, the usual functional parameters are lost and social and sociopsychological parameters change. For the organization, the staff movement provides an opportunity to attract people with new views, rejuvenate the staff, stimulate change, increase internal activity and flexibility. But it creates additional costs associated with recruitment and temporary replacement, training, communication disorders, large losses of working time, falling discipline, a decline in quality.

Increased staff turnover, regardless of the reasons, reduces staffing, the efficiency of training costs, distracts from the responsibilities of highly qualified professionals, the need to help newcomers, worsens the moral and psychological climate, reduces productivity in those who are going to leave, and as a result causes economic losses. The role of social information is growing in the formation of the personnel management system at Technopolis-1 LLC, and especially in the flow processes, the generalized results of which are a necessary basis for the development of social development plans for the team. Social information in personnel management at the enterprise is understood as a set of legal, sociological, socio-psychological and pedagogical awareness of personnel services employees, which contributes to the directed influence on the course of social processes in the team and education of workers. In other words, social information is the information necessary for the head to set, choose the means and implement the tasks of formation and stabilization of production teams and social management in general.

To implement the personnel development strategy at Technopolis-1 LLC, it is necessary to implement a process approach, according to which personnel development is a business process, a sequence of actions, starting with the introduction of the necessary resources and ending with a certain result (product). Elements of the business process of human resources development are its types, forms, methods, specific tools [12]. The main types of training that are relevant for Technopolis-1 LLC in developing a personnel management strategy are training by solving real problems at the workplace, participation in projects; performance of new duties; on-the-job training with a more experienced employee: mentoring, coaching; training in classrooms: lectures, seminars, trainings [3].

The effectiveness of these species is different. In the first case, it is $70 \%$, in the second $20 \%$, in the third - only $10 \%$. However, the costs of all these types have the opposite tendency: they are the highest for classroom classes, while on-the-job training costs the least [5].

Therefore, the organization of on-the-job training is especially promising for Technopolis-1 LLC, and the responsibility for its results should be transferred both to personnel managers and to the same extent to the employee and his manager. In order to overcome such common shortcomings in the organization of the personnel development process as improper training planning, untimely feedback on learning outcomes, the inconsistency of training with the organizational development strategy, Technopolis-1 LLC must introduce an application for training. It should indicate the business need for training right now, the practical value of training to perform immediate duties, the competencies that need to be acquired by the employee. Technopolis-1 LLC should also introduce a step-by-step form of training efficiency assessment. At the end of the training or seminar, the employee fills in a form-assessment of its effectiveness, and after 3 months the employee re-analyzes: what knowledge and skills he regularly uses in the work, only from time to time, how useful training was to improve his work. 
ФІНАНСОВІ РЕСУРСИ: ПРОБЛЕМИ ФОРМУВАННЯ ТА ВИКОРИСТАННЯ

The problem of personnel management of Technopolis-1 LLC is also the social insecurity of the staff, the high probability of errors due to the lack of a separate staff member. Today, the duties of a staff member at Technopolis-1 LLC are performed by an accountant. As its functions are limited only to the design of personnel documentation, respectively, work to improve the personnel management system, its motivation, improving the socio-psychological climate is not performed. There are also no special methods of testing, certification of employees, which negatively affects the organization of work at the enterprise.

Technopolis-1 LLC is proposed to take into account all these shortcomings and enshrine them in internal documents. It is also advisable to improve job descriptions at the company, as the number of staff changed during 2017-2019, the responsibilities of dismissed employees were redistributed accordingly among the remaining employees, but all this took place orally, which does not ensure proper performance of transferred responsibilities.

On the basis of the conducted research it is possible to define the following directions of increase of efficiency of management of the personnel on Open Company "Technopolis-1":

1. the organization of continuous training and advanced training of the personnel of the enterprise on the basis of drawing up of annual plans of development of the personnel;

2. expansion of the system of intangible incentives, which will prevent the growth of staff turnover;

3. optimization of internal personnel documentation in accordance with the needs of today, revise job descriptions, rules of internal labor regulations and regulations on remuneration and bonuses;

4. implementation of measures to improve the socio-psychological climate in the team, which will create a relationship of trust in the team and increase efficiency;

5. improving the organization of workplaces in the direction of providing them with modern equipment and the necessary accessories and devices.

All the proposed measures are aimed at increasing the productivity of employees.

Evaluation of the effectiveness of improving the management of personnel of Technopolis-1 LLC using the method of expert evaluations is presented in table 4. The experts were employees of the enterprise. Experts were asked to assess the possible level of productivity growth of employees as a result of the implementation of measures to improve personnel management.

Table 4

Expert assessment of the effectiveness of improving personnel management at Technopolis-1 LLC

\begin{tabular}{|c|c|c|c|c|}
\hline \multirow{2}{*}{ Direction of improvement } & \multicolumn{3}{|c|}{ Expert evaluation, \% } & \multirow{2}{*}{ Mean } \\
\hline & 1 & 2 & 3 & \\
\hline Introduction of innovative technologies of personnel management & 4 & 6 & 5 & 5 \\
\hline Improving the personnel development system & 3 & 3 & 4 & 3,3 \\
\hline Optimization of motivational management function & 2 & 2 & 2 & 2 \\
\hline Improving the level of qualification of administrative and managerial staff & 5 & 4 & 4 & 4,7 \\
\hline The general level of productivity growth & & & & 15 \\
\hline
\end{tabular}

Thus, according to experts, the improvement of the personnel management strategy of Technopolis-1 LLC will contribute to the growth of labor productivity by $15 \%$.

Conclusions The analysis of the personnel management system of the enterprise and the definition of the main problems allowed to suggest the following ways of improvement: introduction of innovative technologies of personnel management; improvement of the personnel development system; optimization of the motivational management function; raising the level of qualification of administrative and managerial staff. As a result of improving the personnel management strategy at Technopolis-1 LLC, labor productivity, net income, net profit and staff profitability are projected to grow over the next three years. 
ФІНАНСОВІ РЕСУРСИ: ПРОБЛЕМИ ФОРМУВАННЯ ТА ВИКОРИСТАННЯ

In order to improve the strategy of personnel management of the enterprise, it is necessary to organize training and retraining of employees and training of administrative and managerial staff. Particularly promising is the organization of on-the-job training, with the transfer of responsibility for its results to both HR managers and, to the same extent, to employees and their managers. It is also proposed to introduce a competent approach to personnel management, regularly measure the effectiveness and qualification of staff (performance appraisal programs), and maintain staff loyalty with the help of corporate resources, corporate culture and corporate culture. These measures will increase the productivity of staff, and, accordingly, the efficiency of the enterprise.

\section{References}

1. Bazhan, L. I., Yablokov, I. V. (2016). Kontseptualni zasady povedinkovykh nauk yak teorii liudskykh resursiv [Conceptual principles of behavioral sciences as theories of human resources]. Ekonomiko-matematychne modeliuvannia sotsialno-ekonomichnykh system - Economic and mathematical modeling of socio-economic systems, 21, 413-433 [in Ukrainian].

2. Barskyi, Yu. M., Sahan M. V. (2018). Konkurentospromozhnist ta pryrist trudovykh pokaznykiv - zaporuka efektyvnoi diialnosti pidpryiemstva [Competitiveness and growth of labor indicators - a guarantee of effective activity of the enterprise]. Ekonomichnyi forum: nauk. zhurnal Economic Forum: Scientific Journal, 3, 150-159 [in Ukrainian].

3. Bosak, O. V. (2016). Profesiine navchannia personalu yak faktor rozvytku liudskykh resursiv orhanizatsii [Professional training of personnel as a factor in the development of human resources of the organization]. Upravlinnia liudskym potentsialom - Management of human potential, 3, 320-323 [in Ukrainian].

4. Voloshenko, O. O., Skriaha, N. V. (2016). Osoblyvosti stratehichnoho upravlinnia personalom u torhivli [Peculiarities of strategic personnel management in trade]. Investytsii: praktyka ta dosvid Investments: practice and experience, 22, 35-38 [in Ukrainian].

5. Horpynchenko, O. V. (2016). Systema pidhotovky kadriv: svitovyi dosvid ta tendentsii rozvytku v Ukraini [System of personnel training: world experience and development trends in Ukraine]. Naukovyy visnyk Uzhhorods'koho natsional'noho universytetu. Seriya: Mizhnarodni ekonomichni vidnosyny ta svitove hospodarstvo - Scientific Bulletin of Uzhhorod National University. Series: International Economic Relations and the World Economy, 8 (1), 45-48 [in Ukrainian].

6. Hurchenkov, O. P. (2016). Formuvannia systemy upravlinnia personalom ta otsinka yii efektyvnosti [Formation of the personnel management system and evaluation of its effectiveness]. Ekonomika: realii chasu - Economics: the realities of time, 2, 60-72. Retrieved from http://nbuv.gov.ua/UJRN/econrch_2016_2_11.

7. Doroshenko, K. A. (2015). Efektyvnist upravlinnia personalom v orhanizatsii [Effectiveness of the personnel management in the organization]. Tekhnolohii ta dyzain - Technology and Design, 3. Retrieved from http://nbuv.gov.ua/UJRN/td_2015_3_17.

8. Kovtun, Ye. I. (2016). Analiz systemy upravlinnia personalom pidpryiemstva ta rozrobka zakhodiv shchodo yii udoskonalennia [Analysis of the personnel management system of the enterprise and development of the measures for its improvement]. Molodyi vcheny - Young Scientist, 6, 46-50 [in Ukrainian].

9. Kravets, I. M., Rushanian, S. S. (2016). Upravlinnia personalom maloho pidpryiemstva: osoblyvosti ta shliakhy vdoskonalennia [Personnel management of a small enterprise: features and ways to improve]. Naukovyi visnyk Uzhhorodskoho natsionalnoho universytetu. Seriia: Mizhnarodni ekonomichni vidnosyny ta svitove hospodarstvo - Scientific Bulletin of Uzhgorod National University. Series: International Economic Relations and the World Economy, 9, 88-92 [in Ukrainian].

10. Kudria, Ya. V. (2011). Novi pidkhody do kadrovoi polityky v upravlinni personalom [New approaches to personnel policy in personnel management]. Problemy nauky - Problems of science, 7, 21-26 [in Ukrainian].

11. Leli, Yu. H. (2013). Suchasni systemy upravlinnia personalom ta yikh vplyv na efektyvnist roboty pidpryiemstva [Modern personnel management systems and their impact on the efficiency of the enterprise]. Teoretychni i praktychni aspekty ekonomiky ta intelektualnoi vlasnosti - Theoretical and practical aspects of economics and intellectual property, 1(2), $95-98$ [in Ukrainian]. 
ФІНАНСОВІ РЕСУРСИ: ПРОБЛЕМИ ФОРМУВАННЯ ТА ВИКОРИСТАННЯ

12. Liubymova, K. O. (2017). Svitovyi dosvid profesiinoho navchannia personalu pidpryiemstv [World experience of professional training of the personnel of the enterprises]. Ekonomika ta upravlinnia pidpryiemstvom - Economics and the enterprise management, 3, 58-61 [in Ukrainian].

13. Rechka, K. M. (2018). Zahalni rysy upravlinnia personalom u systemi menedzhmentu ahrarnoho pidpryiemstva [General features of the personnel management in the management system of an agrarian enterprise]. Ekonomika i derzhava - Economy and State, 3, 67-70 [in Ukrainian].

14. Sivashenko, T. (2012). Udoskonalennia systemy upravlinnia personalom pidpryiemstva [Improving the personnel management system of the enterprise]. Ekonomichnyi analiz - Economic analysis, 11(3), 48-50 [in Ukrainian].

15. Tretiak O. P. (2014). Suchasni personal-tekhnolohii u systemi upravlinnia personalom na pidpryiemstvi [Modern personnel technologies in the personnel management system at the enterprise]. Naukovyi visnyk NLTU Ukrainy - Scientific Bulletin of NLTU of Ukraine, 24.4, 389-397 [in Ukrainian].

16. Shymanovska-Dianych, L. M. (2016). Upravlinnia rozvytkom personalu orhanizatsii: teoriia $i$ praktyka [Management of the personnel development of the enterprise: theory and practice]. Poltava: PUET [in Ukrainian].

17. Shliakhta, O. M. (2012). SWOT- analiz yak instrument stratehichnoho menedzhmentu pidpryiemstva [SWOT-analysis as an instrument of strategic management of the enterprise]. Ekonomichnyi prostir-Economic space, 68, 301-309 [in Ukrainian].

\section{References (in language original)}

1. Бажан Л. І., Яблоков I. В. Концептуальні засади поведінкових наук як теорії людських ресурсів. Економіко-математичне моделювання соціально-економічних систем : зб. наук. пр. Київ : МННЦІТС НАН та МОН України, 2016. Вип. 21. С. 413-433.

2. Барський Ю. М., Саган М. В. Конкурентоспроможність та приріст трудових показників запорука ефективної діяльності підприємства. Економічний форум наук. журнал. 2018. Вип. 3. C. $150-159$.

3. Босак О. В. Професійне навчання персоналу як фактор розвитку людських ресурсів організації. Управління людським потенціалом. 2016. № 3. С. 320-323.

4. Волошенко О. О., Скряга Н. В. Особливості стратегічного управління персоналом у торгівлі. Інвестииії: практика та досвід. 2016. № 22. С. 35-38.

5. Горпинченко О. В. Система підготовки кадрів: світовий досвід та тенденції розвитку в Україні. Науковий вісник Ужггородського наиіонального університету. Серія: Міжнародні економічні відносини та світове господарство. 2016. Вип. 8(1). С. 45-48.

6. Гурченков О. П. Формування системи управління персоналом та оцінка іiі ефективності. Економіка: реалії часу. 2016. № 2. C. 60-72. URL: http://nbuv.gov.ua/UJRN/econrch_2016_2_11.

7. Дорошенко К. А. Ефективність управління персоналом в організації. Технологї̈ $\overline{m a} \partial u$ зайн. 2015. № 3. URL: http://nbuv.gov.ua/UJRN/td_2015_3_17.

8. Ковтун Є. I. Аналіз системи управління персоналом підприємства та розробка заходів щодо її удосконалення. Молодий вчений. 2016. № 6. С. 46-50.

9. Кравець І. М., Рушанян С. С. Управління персоналом малого підприємства: особливості та шляхи вдосконалення. Науковий вісник Ужгородського начіонального університету. Серія: Міжнародні економічні відносини та світове господарство. 2016. Вип. 9. С. 88-92.

10. Кудря Я. В. Нові підходи до кадрової політики в управлінні персоналом. Проблеми науки. 2011. № 7. C. 21-26.

11. Лелі Ю. Г. Сучасні системи управління персоналом та їх вплив на ефективність роботи підприємства. Теоретичні і практичні аспекти економіки та інтелектуальної власності. 2013. Вип. 1(2). С. 95-98.

12. Любимова К. О. Світовий досвід професійного навчання персоналу підприємств. Економіка та управління підприємством. 2017. № 3. С. 58-61.

13. Речка К. М. Загальні риси управління персоналом у системі менеджменту аграрного підприємства. Економіка і держсава. 2018. № 3. С. 67-70.

14. Сівашенко Т. Удосконалення системи управління персоналом підприємства. Економічний аналіз. 2012. Т. 11(3). С. 48-50. 
ФІНАНСОВІ РЕСУРСИ: ПРОБЛЕМИ ФОРМУВАННЯ ТА ВИКОРИСТАННЯ

15. Третьяк О. П. Сучасні персонал-технології у системі управління персоналом на підприємстві. Науковий вісник НЛТУ України. 2014. Вип. 24.4. С. 389-397.

16. Шимановська-Діанич Л. М. Управління розвитком персоналу організації: теорія і практика : монографія. Полтава : ПУЕТ, 2016. 462 с.

17. Шляхта O. M. SWOT-аналіз як інструмент стратегічного менеджменту підприємства. Економічний простір. 2012. № 68. С. 301-309.

Oliychenko Igor - Doctor of Public Administration, Professor, Professor of the Department of Management and

Public Service, Chernihiv National University of Technology (95 Shevchenka Str., 14035 Chernihiv, Ukraine).

Олійченко Ігор Михайлович - доктор наук з державного управління, професор, професор кафедри мене-

джменту та державної служби, Чернігівський національний технологічний університет (вул. Шевченка, 95 ,

м. Чернігів, 14035, Україна).

Олейченко Игорь Михайлович - доктор наук по государственному управлению, профессор, профессор кафедры менеджмента и государственной службы, Черниговский национальный технологический университет (ул. Шевченко, 95, г. Чернигов, 14035, Украина).

E-mail: oimdigor@gmail.com

ORCID: https://orcid.org/0000-0001-8424-5432

ResearcherID: I-4025-2016

Ditkovska Maryna - PhD in Public Administration, Associate Professor, Associate Professor of the Department of Management and Public Service, Chernihiv National University of Technology (95 Shevchenka Str., 14035 Chernihiv, Ukraine).

Дітковська Марина Юріївна - кандидат наук з державного управління, доцент, доцент кафедри менеджменту та державної служби, Чернігівський національний технологічний університет (вул. Шевченка, 95, м. Чернігів, 14035, Україна).

Дитковская Марина Юрьевна - кандидат наук по государственному управлению, доцент, доцент кафедры менеджмента и государственной службы, Черниговский национальный технологический университет (ул. Шевченко, 95, г. Чернигов, 14035, Украина).

E-mail: oimd3@ukr.net

ORCID: https://orcid.org/0000-0001-9286-5121

ResearcherID: I-4040-2016 